\title{
Effect of Silver Nanoparticles and Antibiotics on Antibiotic Resistance Genes in Anaerobic Digestion
}

\author{
Jennifer H. Miller ${ }^{1 *}$, John T. Novak ${ }^{1}$, William R. Knocke ${ }^{1}$, Katherine Young ${ }^{1}$, Yanjuan Hong ${ }^{1}$, Peter J. Vikesland ${ }^{1}$, \\ Matthew S. Hull ${ }^{1,2}$, Amy Pruden ${ }^{1}$
}

\begin{abstract}
Water resource recovery facilities have been described as creating breeding ground conditions for the selection, transfer, and dissemination of antibiotic resistance genes (ARGs) among various bacteria. The objective of this study was to determine the effect of direct addition of antibiotic and silver nanoparticles (Ag NPs, or nanosilver) on the occurrence of ARGs in thermophilic anaerobic digesters. Test thermophilic digesters were amended with environmentally-relevant concentrations of Ag NP $(0.01,0.1$, and $1.0 \mathrm{mg}-\mathrm{Ag} / \mathrm{L}$; corresponding to $\approx 0.7,7.0$, and $70 \mathrm{mg}-\mathrm{Ag} / \mathrm{kg}$ total solids) and sulfamethoxazole (SMX) that span susceptible to resistant classifications $(1,5$, and $50 \mathrm{mg} / \mathrm{L})$ as potential selection pressures for ARGs. Tetracycline $(\operatorname{tet}(\mathrm{O})$, tet $(\mathrm{W}))$ and sulfonamide (sulI, sulII) ARGs and the integrase enzyme gene (intI1) associated with Class 1 integrons were measured in raw sludge, test thermophilic digesters, a control thermophilic digester, and a control mesophilic digester. There was no apparent effect of Ag NPs on thermophilic anaerobic digester performance. The maximum SMX addition $(50 \mathrm{mg} / \mathrm{L})$ resulted in accumulation of volatile fatty acids and low $\mathrm{pH}$, alkalinity, and volatile solids reduction. There was no significant difference between ARG gene copy numbers (absolute or normalized to $16 \mathrm{~S}$ rRNA genes) in amended thermophilic digesters and the control thermophilic digester. Antibiotic resistance gene copy numbers in digested sludge ranged from $10^{3}$ to $10^{6}$ copies per $\mu \mathrm{L}\left(\approx 8 \times 10^{1}\right.$ to 8 $\times 10^{4}$ copies per $\mu \mathrm{g}$ ) of sludge as result of a 1-log reduction of ARGs (2$\log$ reduction for int $\mathrm{I} 1)$. Quantities of the five ARGs in raw sludge ranged from $10^{4}$ to $10^{8}$ copies per $\mu \mathrm{L}\left(\approx 4 \times 10^{2}\right.$ to $4 \times 10^{6}$ per $\left.\mu \mathrm{g}\right)$ of sludge. Test and control thermophilic digesters $\left(53{ }^{\circ} \mathrm{C}, 12\right.$-day solids retention time [SRT]) consistently reduced but did not eliminate levels of all analyzed genes. The mesophilic digester $\left(37^{\circ} \mathrm{C}, 20\right.$-day SRT) also reduced levels of sulI, sulII, and int $\mathrm{I} 1$ genes, but levels of $\operatorname{tet}(\mathrm{O})$ and $\operatorname{tet}(\mathrm{W})$ were the same or higher than in raw sludge. Antibiotic resistance gene reductions remained constant despite the application of selection pressures, which suggests that digester operating conditions are a strong governing factor of the bacterial community composition and thus the prevalence of ARGs. Water Environ. Res., 85, 411 (2013).
\end{abstract}

KEYWORDS: silver nanoparticles (Ag NPs), nanosilver, ionic silver, thermophilic anaerobic digestion, mesophilic anaerobic digestion, antibiotic resistance genes (ARGs), antibiotic, sulfamethoxazole (SMX). doi:10.2175/106143012X13373575831394

\footnotetext{
${ }^{1}$ Charles E. Via, Jr. Department of Civil and Environmental Engineering, Virginia Tech, Blacksburg, Virginia; e-mail address: jhmiller@vt.edu.

${ }^{2}$ Institute for Critical Technology and Applied Science, Virginia Tech, Blacksburg, Virginia.
}

\section{Introduction}

Water resource recovery facilities have been identified as vehicles for the conveyance of pharmaceuticals and silver nanoparticles (Ag NPs or nanosilver) in addition to antibiotic resistant bacteria (ARB) and antibiotic resistance genes (ARGs) from anthropogenic sources to the environment. Kolpin et al. (2002) raised the awareness of pharmaceuticals (including antibiotics) in the environment, sourced in part from water resource recovery facilities. These concerns have now grown to include engineered nanomaterials such as Ag NPs that are used primarily as antimicrobial agents in a wide variety of consumer products. The Project on Emerging Nanotechnologies reports that as of March 2011, Ag NPs are used in 24\% of 1300 commercially available, nanotechnology-enabled products. Benn and Westerhoff (2008) reported that 10 to 30\% of silver contained in a tested Ag NPs-amended sock fabric was released to washwater as Ag NPs. Although the percentage and overall silver mass varied widely by manufacturer and sock type, their findings underscore the anticipated increase of Ag NPs loading to water resource recovery facilities. Lastly, antibiotic resistance genes are also emerging environmental contaminants of concern (Pruden et al., 2006).

Antibiotic resistance genes genetically encode a molecular mechanism such as efflux pumps, target modification, or antibiotic inactivation or degradation that enables bacteria to circumvent or diffuse antibiotic action. Many infectious diseases are increasingly difficult to treat as a result of antimicrobialresistant pathogens (NIAID, 2012). Because pathogenic bacteria differ little from commensal or environmental bacteria in basic cell functions that are the target of antibiotics, genetic exchange of mobile resistance elements occurs in the environment and not just in clinical settings (Summers, 2002). Wastewater treatment plants with high nutrient loadings and dense microbial populations have been specifically identified as potential breeding grounds for amplification and transfer of ARGs (Kim and Aga, 2007).

An overarching hypothesis of this study is that antibiotics and Ag NPs could act as selection agents for ARG proliferation in anaerobic digesters. Kohanski et al. (2010) reported that sublethal antibiotic concentrations produced an oxidative stress response that induced mutagenesis and led to an increase in resistance to multiple antibiotics. In the environment, low concentrations of antibiotics can act as signals that initiate transcription of genes to alter metabolism and growth (Allen et 
al., 2010; Davies et al., 2006), suggesting that antibiotics have biological consequences even at sub-inhibitory concentrations.

Co-selection of antibiotic and silver resistance genes in the environment has been documented (Cunningham and Lin, 2010; Loh et al., 2009). Genes encoding silver resistance and antibiotic resistance can be found on the same plasmid or in the same bacteria on different plasmids or other loci. Integrons, which are multi-gene cassettes that can encode many different ARGs under a common promoter, can also facilitate co-selection of ARGs. Thus, selection pressure exerted by one antibiotic might select for ARGs corresponding to distinct antibiotics within the gene cassette of the integron. For example, sulI is an ARG that incurs resistance against sulfonamides, including sulfamethoxazole (SMX), and is located in the conservative region of Class I integrons. Persistent SMX could co-select for ARGs encoding resistance to other clinically important antibiotics that are colocated on integrons.

To date, three published studies have examined the effect of anaerobic digestion on ARGs, Diehl and LaPara (2010), Ghosh et al. (2009), and Ma et al. (2011). Collectively, full- and lab-scale studies measured ARG numbers and ratios (ARG gene copy number normalized to $16 \mathrm{~S}$ bacterial rRNA) for tetracycline, sulfonamide, erythromycin, and Class 1 integrase genes in thermophilic and mesophilic digestion. All genes showed some reduction during thermophilic treatment. However, results for tetracycline genes in mesophilic digestion varied, which suggests that the digester microbial community and the operating conditions that influence the development and maintenance of that community play an important role in determining ARG fate. Aside from temperature, digester operating conditions and raw sludge characteristics (such as ARG composition or antibiotic and Ag NPs concentration) that might affect digester ARG composition have not been investigated.

The fate and toxicity of ionic silver in wastewater processes have been reported in the literature (Bard et al., 1976; Lytle, 1984; Pavlostathis and Maeng, 2000; Shafer et al., 1998). However, concerns have recently arisen as to whether Ag NPs pose hazards distinct from ionic silver with respect to wastewater microorganisms, toxicity, and fate (Choi and $\mathrm{Hu}$, 2009; Liang et al., 2010). Kiser et al. (2010) reported 97\% removal of Ag NPs by sorption to activated sludge biomass; thus, Ag NPs will likely accumulate from influent wastewater in sludge sent to digestion. More recently, Yang et al. (2012) reported that an Ag NP concentration of $<40 \mathrm{mg} / \mathrm{L}$ had a negligible effect on anaerobic digestion as assessed by methane production, $\mathrm{pH}$, volatile fatty acids (VFAs), and methanogen diversity and population.

With respect to SMX addition, Fountoulakis et al. (2004) did not measure any inhibition of acetoclastic methanogenesis under mesophilic conditions by SMX at concentrations up to $400 \mathrm{mg} / \mathrm{L}$ as measured by specific methanogenic activity. The effects of SMX on thermophilic anaerobic digestion processes have also not been reported.

The purpose of this study was to investigate (1) the fate of ARGs in thermophilic anaerobic digestion, (2) the effect of artificially-applied antibiotic (SMX) and antimicrobial (Ag NPs) selection pressures on ARGs and anaerobic digester performance, and (3) possible co-selection of multiple ARGs via integrons.

Sulfamethoxazole, citrate-coated Ag NPs, and ionic silver were spiked separately at increasing concentration levels into raw sludge and fed daily to lab-scale digesters. Anaerobic mesophilic and thermophilic control digesters (no amendments) were also operated for comparison. Silver levels were selected to mirror estimated environmentally-relevant concentrations of $\mathrm{Ag}$ NPs, ranging from 0.01 to $1 \mathrm{mg}-\mathrm{Ag} / \mathrm{L}$ (Benn and Westerhoff, 2008; Gottschalk et al., 2009; Muhling et al., 2009; U.S. EPA, 2009), rather than minimum inhibitory values (MIC). The latter values have been reported to range from 0.02 to $65 \mathrm{mg} / \mathrm{L}$ in susceptible bacteria and up to $2675 \mathrm{mg} / \mathrm{L}$ in resistant bacteria (Clement and Jarrett, 1994). Bard et al. (1976) found silver nitrate concentrations of $10 \mathrm{mg}-\mathrm{Ag} / \mathrm{L}$ inhibited wastewater bacteria. Sulfamethoxazole concentrations (1, 5, and $50 \mathrm{mg} / \mathrm{L}$ ) were selected based on background SMX concentrations in biosolids (U.S. EPA, 2009), and MIC values corresponding to susceptible $(<2$ to $38 \mathrm{mg} / \mathrm{L})$ and resistant $(>8$ to $150 \mathrm{mg} / \mathrm{L})$ as reported in Nagulapaly et al. (2009). Background SMX concentrations in wastewater have been reported to range from 0.1 to $5 \mu \mathrm{g} / \mathrm{L}$ and from 3.91 to $651 \mu \mathrm{g} / \mathrm{kg}(0.05$ to $7.8 \mathrm{mg} / \mathrm{L}$, assuming $1.2 \%$ total solids; U.S. EPA, 2009) in biosolids.

Bacterial 16S rRNA genes and ARGs encoding resistance to sulfonamides (sulI, sulII) and tetracycline $(\operatorname{tet}(\mathrm{O})$, tet $(\mathrm{W}))$, as well as a gene encoding the integrase enzyme (intI1) that is found in Class 1 integrons, were measured in the raw sludge feed and digested sludge (i.e., bioreactor effluent). Class 1 integrons are the largest, most prevalent integron class and contain most integron-associated ARGs. sulI is located in the conservative region of Class I integrons and encodes resistance to sulfonamides such as SMX. ARGs tet $(\mathrm{O})$ and tet $(\mathrm{W})$, which enable resistance to tetracycline by protecting ribosomes, were targeted because they have been associated with wastewater sources (Storteboom et al., 2010). They also exhibit variable treatment efficiencies within mesophilic digestion (Diehl and LaPara, 2010; Ma et al., 2011)

\section{Methodology}

Digester Operation. A total of four 15-L, 12-day solids retention time $(\mathrm{SRT})$ thermophilic $\left(53^{\circ} \mathrm{C}\right)$ digesters and one 10 L, 20-day SRT mesophilic $\left(37^{\circ} \mathrm{C}\right)$ digester were fed raw sludge daily. Three of the thermophilic digesters were test digesters and received feed with Ag NPs, silver nitrate, or SMX at one of three concentration levels. One thermophilic and one mesophilic digester with no amendments were also included as controls.

High density polyethylene cone fermenters (Hobby Beverage Equipment Company, Temecula, California) with nominal volumes of 6.5 gallons $(24.6 \mathrm{~L})$ were fed daily with a $70 \%$ primary sludge and $30 \%$ thickened waste activated sludge mixture from the Christiansburg Wastewater Treatment Plant. This facility predominantly receives residential wastewater with minimal industrial and no hospital contributions. The mixture was diluted with tap water to $2.5 \%$ total solids to both maintain a consistent feed to the digesters and to reduce variations in operating parameters (e.g., $\mathrm{pH}$, alkalinity, VFAs, volatile solids reduction [VSR]). During the study period, raw sludge was collected from the plant every 4 to 6 weeks and stored at $4{ }^{\circ} \mathrm{C}$ until added to the digesters. Total solids, volatile solids, and $\mathrm{pH}$ of the raw sludge were routinely measured to ensure consistency of the feed sludge. A peristaltic pump was used to mix digester contents by recycling headspace gas to the bottom of the cone digester. Evolved gases were collected in 25-L Tedlar bags (SKC, Inc., Eighty Four, Pennsylvania). All digesters were maintained at $37^{\circ} \mathrm{C}$. 
The mesophilic anaerobic digester was operated at an active volume of $10 \mathrm{~L}$ (2.6 gallons), with a 20 -day SRT, and at $37{ }^{\circ} \mathrm{C}$ that was achieved from ambient conditions. The digester was initiated using $5 \mathrm{~L}$ of digested sludge seed from the Christiansburg Wastewater Treatment Plant. A total of $0.5 \mathrm{~L}$ of feed sludge mixture was added per day until the $10 \mathrm{~L}$ operating volume was reached. All four thermophilic anaerobic digesters were operated at an active volume of $15 \mathrm{~L}, 12$-day SRT, and heated to a target temperature of $53{ }^{\circ} \mathrm{C}$ using electric heating tape with a temperature controller (Model No. BSAT 101-100, Thermolyne, Dubuque, Iowa). Temperatures in the thermophilic digesters over the duration of the study were $52.0 \pm 1.3,52.7$ $\pm 1.3,52.2 \pm 1.8$, and $53.2 \pm 1.7{ }^{\circ} \mathrm{C}$ for Ag NPs, ionic silver, SMX, and thermo control, respectively. Each digester was seeded with digested sludge from laboratory thermophilic anaerobic digesters (temperatures ranged from 48 to $57{ }^{\circ} \mathrm{C}$ ) and fed with primary and secondary solids from the District of Columbia Water and Sewer Authority Blue Plains Advanced Wastewater Treatment Plant. The start-up of mesophilic and thermophilic digesters occurred for 6 months prior to this 6-month study.

Digester Performance Monitoring. Total and volatile solids (Method 2540-G), total alkalinity (Method 2320-G), pH (Method 4500), and gas volume (Method 2720) were analyzed as specified in Standard Methods (APHA et al., 1995). Headspace methane and carbon dioxide were analyzed using a Shimadzu Gas Chromatograph (Model GC-14A, Columbia, Maryland) with a thermal conductivity detector (TCD) as described in Wilson et al. (2008). Volatile fatty acids were measured using a gas chromatograph with flame ionization detector per Wilson et al. (2008). Individual acid concentrations are converted on a theoretical oxygen demand basis and summed to report total VFA as $\mathrm{mg} / \mathrm{L}$ as acetate.

Total silver was measured in digested sludge from each digester prior to the start of the study to establish a baseline, and ranged from 0.9 to $9.6 \mathrm{mg} \mathrm{Ag/L}$. Notably, these concentrations were higher than reported by the Christiansburg Wastewater Treatment Plant where annual total silver concentration in biosolids from 2009 to 2011 were reported as $<5.6 \mathrm{mg} / \mathrm{kg}, 22$ $\mathrm{mg} / \mathrm{kg}$, and $<14.9 \mathrm{mg} / \mathrm{kg}$ (equivalent to $0.07,0.19$, and $0.26 \mathrm{mg}$ $\mathrm{Ag} / \mathrm{L}$, assuming $1.2 \%$ total solids).

Dosing of Selection Pressures. Following start-up, all digesters received raw sludge without amendment to establish a baseline and to ascertain typical variation of ARG concentrations between digesters fed the same raw sludge. Digester performances were monitored and samples analyzed by quantitative polymerase chain reaction (QPCR) over 3 SRTs. Antibiotic resistance gene ratios and un-normalized ARGs were the same $(p<0.05)$ in digested sludge from all thermophilic digesters during this baseline time period (data not shown).

Following the baseline, test digesters were amended with Ag NPs, ionic silver, or SMX at the following three sequential concentration levels: Level 1 (0.01 mg-Ag/L Ag NPs, $0.01 \mathrm{mg}$ $\mathrm{Ag} / \mathrm{L}$ ionic Ag, or $1 \mathrm{mg} / \mathrm{L} \mathrm{SMX);} \mathrm{Level} 2$ (0.1 mg-Ag/L Ag NPs, $0.1 \mathrm{mg}-\mathrm{Ag} / \mathrm{L}$ ionic Ag, or $5 \mathrm{mg} / \mathrm{L} \mathrm{SMX}$ ); and Level 3 (1.0 mg-Ag/ L Ag NPs, $1.0 \mathrm{mg}-\mathrm{Ag} / \mathrm{L}$ ionic Ag, or $50 \mathrm{mg} / \mathrm{L} \mathrm{SMX).} \mathrm{On} \mathrm{Day} 0$ of each concentration level, the appropriate volume of stock solution (or deionized water for control digesters) was added to a given digester to achieve $25 \%$ of the target concentration. Thereafter, the daily feed mixture was amended with Ag NPs, ionic silver, SMX, or deionized water to avoid shock loading. It was determined that $90 \%$ of the target concentration would be reached within 2 SRTs. After 2 SRTs (starting Day 25), low variation in VSR and $\mathrm{pH}$ (standard deviation $<10 \%$ or less of average value) were used to verify steady state conditions and digester performance, and QPCR samples were collected for an additional 1.5 SRTs thereafter.

Silver Nanoparticles Synthesis. Silver nanoparticles were synthesized using a method modified from Solomon et al. (2007) with stabilization provided by sodium citrate $(2 \mathrm{mM})$. The final silver concentration was $10.4 \mathrm{mg}-\mathrm{Ag} / \mathrm{L}$ as measured by inductively coupled plasma mass spectrometer. Ultravioletvisible (UV-Vis) spectroscopy measurements were obtained using a Cary 5000 UV-Vis-NIR spectrophotometer (Agilent Technologies, Santa Clara, California). Estimates of hydrodynamic diameter (Z-average, $44.6 \pm 3.9 \mathrm{~nm}$ ) were obtained using a Malvern Zetasizer NanoZS (Malvern, U.K.). The polydispersity index ranged from 0.524 to 0.885 , which suggests that suspensions were similarly monodisperse.

Ionic Silver Preparation. Silver nitrate (Sigma Aldrich, St. Louis, Missouri) was dissolved in distilled water to a concentration of $10.4 \mathrm{mg}-\mathrm{Ag} / \mathrm{L}$.

Sulfamethoxazole Preparation. Sulfamethoxazole (Sigma Aldrich, St. Louis, Missouri) was dissolved in methanol and diluted with distilled water to final concentrations of $500 \mathrm{mg} / \mathrm{L}$ and $100 \mathrm{mg} / \mathrm{L}$.

Quantification of Antibiotic Resistance Genes. Deoxyribonucleic acid was extracted from $250 \mu \mathrm{L}$ of digested sludge from the digesters or raw feed sludge ( $250 \mathrm{mg}$ centrifuged sludge for baseline samples) using FastDNA Soil Kit (MP Biomedicals, Solon, Ohio) according to manufacturer's recommended protocol. Extracted DNA was diluted 50 times to minimize inhibitory effects (Ma et al., 2011). Diluted DNA extracts were stored at $-20{ }^{\circ} \mathrm{C}$ until QPCR analysis for the following bacterial $16 \mathrm{~S}$ rRNA genes: sulI, sulII, tet $(\mathrm{O})$, tet $(\mathrm{W})$, and $\operatorname{int} \mathrm{I} 1$. A $10-\mu \mathrm{L}$ reaction mixture was prepared and consisted of $5.0 \mu \mathrm{L}$ SsoFast Evagreen Supermix (Bio-Rad, Hercules, California), $0.8 \mu \mathrm{L}$ of each $5 \mu \mathrm{M}$ primer (Ma et al., 2011), 2.4 $\mu \mathrm{l}$ of molecular biology-grade water, and $1 \mu \mathrm{L}$ of DNA template. All samples were quantified in triplicate. Standards prepared from serial dilutions of cloned genes ranged from $10^{2}$ to $10^{8}$ gene copies per $\mu \mathrm{L}$. Standards and a reagent blank were included in each run.

Quantification of Methanogen Populations. Diluted DNA extracts were analyzed by QPCR using TaqMan ${ }^{\circledR}$ probes and primers targeting for order-specific 16S rRNA archael genes corresponding to hydrogenotrophic methanogens (Methanobacteriales, Methanococcales, and Methanomicrobiales and an acetoclastic methanogen Methanosarcinales) (Wilson, 2009).

Statistics. Microsoft Excel 2007 was used to calculate averages and standard error for all data. R-2.8.1 was used to perform Student $t$-tests on log ARG gene copy numbers and ARG ratios between (1) test digesters and the thermophilic control digester, and (2) all digesters and the raw sludge feed. A $P$-value of $<0.05$ was considered to indicate a significant difference between means.

\section{Results}

Digester Performance. There was no observed effect of environmentally-relevant concentrations of Ag NPs or ionic silver compounds on thermophilic digester performance. Also, there was no observed effect of SMX addition at concentrations below the MIC (1 and $5 \mathrm{mg}-\mathrm{SMX} / \mathrm{L}$ ). $\mathrm{pH}$ was maintained between 7.4 and 7.6 with alkalinities between 3200 and $4100 \mathrm{mg} /$ 

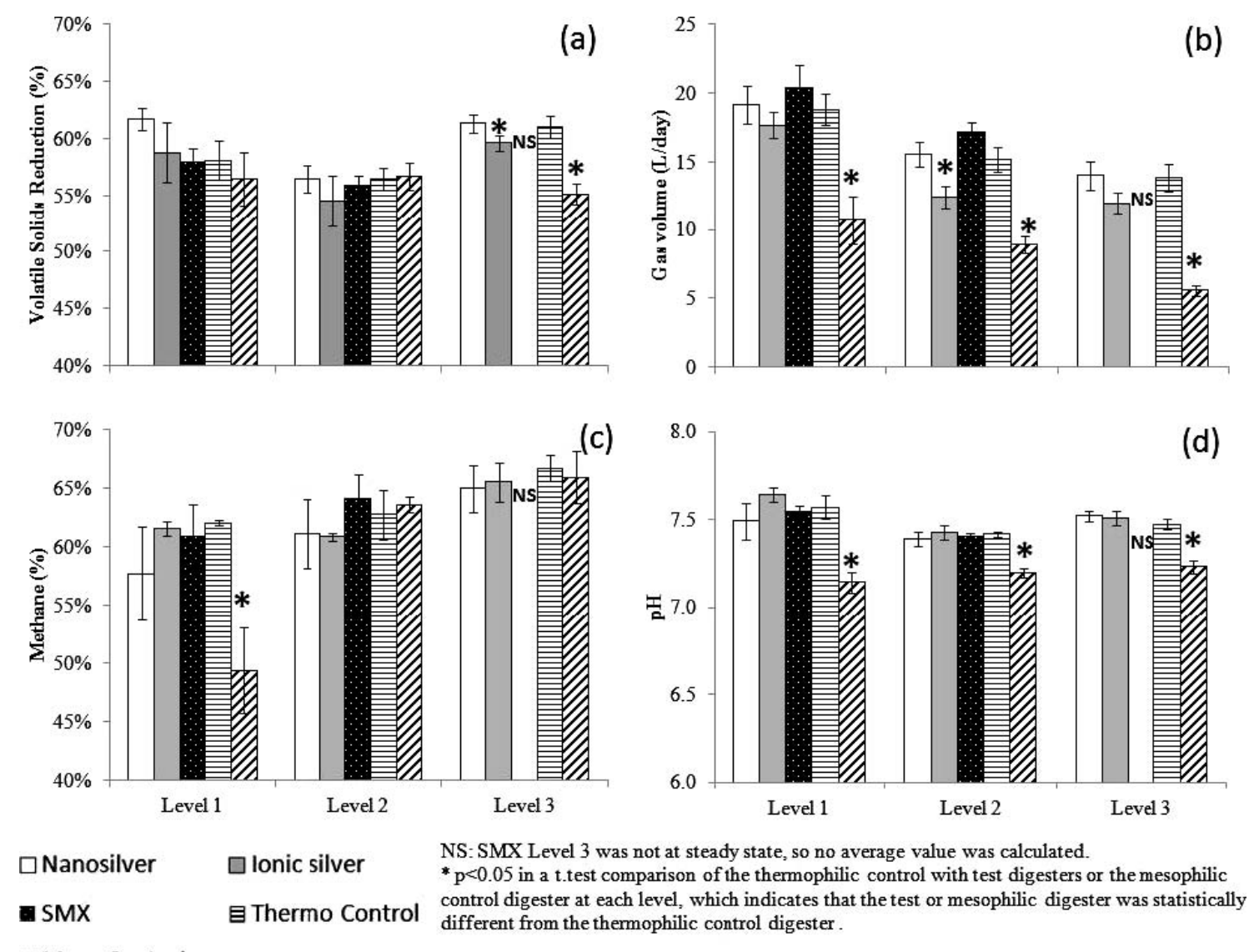

ZMeso Control

Figure 1-Comparison of volatile solids reduction (\%, VSR), pH, gas volume, and methane composition during all dosing levels. Error bars represent standard error of three to six samples collected at steady state every 3 days over 1.5 to 2 solids retention times for dosing Levels 1, 2, and 3.

$\mathrm{L}$ as $\mathrm{CaCO}_{3}$. Volatile solids reduction ranged between 54 to $62 \%$, and total VFAs ranged between 64 and $180 \mathrm{mg}$-acetate/L with acetate and propionate constituting almost all measured VFAs. Statistical analyses of $\mathrm{pH}$, methane gas composition, gas volume, and VSR data showed that all thermophilic test digesters operated comparably to the thermophilic control digester when fed the same raw sludge, except a slightly lower VSR in the ionic silver digester during Level $3(P<0.05$, Figure 1$)$. The mesophilic control digester operated at a lower $\mathrm{pH}$ and produced less gas, which is to be expected given the difference in daily feed volumes. The methane composition of the mesophilic control digester was lower during Level 1 than the thermophilic control because the digester had a small air leak, although this did not appear to affect VSR in Level 1. Level 3 VSR in the mesophilic control was lower than the thermophilic control. This deviation was likely a result of the continued improvement in VSR and stability with digester age in the thermophilic digesters, which tend to require longer acclimation periods, rather than deterioration in the performance of the mesophilic digester. The mesophilic digester VSR performance was consistent across all dosing levels.

Digester performance was adversely affected by the high dose of SMX (50 mg/L). Alkalinity decreased to $2260 \mathrm{mg} / \mathrm{L}$ as $\mathrm{CaCO}_{3}$, and $\mathrm{pH}$ decreased to 6.3 in response to an increase in VFAs. The VSR declined to $40 \%$, at which point SMX dosing was suspended. Gas composition was difficult to interpret because total gas recoveries (i.e., $\mathrm{CO}_{2}+\mathrm{CH}_{4}$ ) increased from $103 \%$ to as much as $114 \%$ during this period. This result could be explained by TCD detection of other unidentified components in the $\mathrm{CO}_{2}$ and $\mathrm{CH}_{4}$ fractions.

Interestingly, there was a $30 \%$ increase in gas volume production during the first few days of SMX addition at 50 $\mathrm{mg} / \mathrm{L}$, followed by a return to the baseline volume production (data not shown). Hydrogen gas concentrations were two to six times the concentration of the thermophilic control digester (data not shown). The color of the digested sludge turned from black to a light brown, which suggests that digestion was incomplete (also supported by VSR measurements), whereas the odor changed from earthy-musty to acidic or vinegar (acetic acid).

Quantitative polymerase chain reaction analysis of sludge samples collected from the SMX digester show that hydrogenotrophic and acetoclastic methanogen populations measured both as gene copy numbers per microliter and gene copy numbers per gram volatile solids were reduced at the time coinciding with reductions in VSR (data not shown). Also, the relative proportion of hydrogenotrophic and acetoclastic methanogens did not change (data not shown).

Effect of Silver Nanoparticles and Sulfamethoxazole on Antibiotic Resistance Genes. The results of QPCR analysis are 


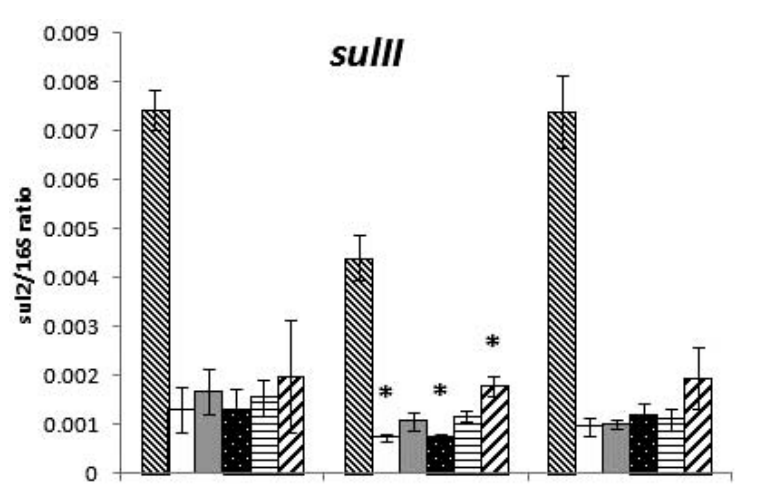

$\mathbb{B}$ Feed

$\square$ Nanosilver

$\square$ lonic silver

a SMX

目 Thermo Control

Meso Control

${ }^{*} p<0.05$ ARG ratio in test digester is different (higher or lower) than the thermophilic control diger.

\# ARG ratio in digester is the same or higher than raw sludge.

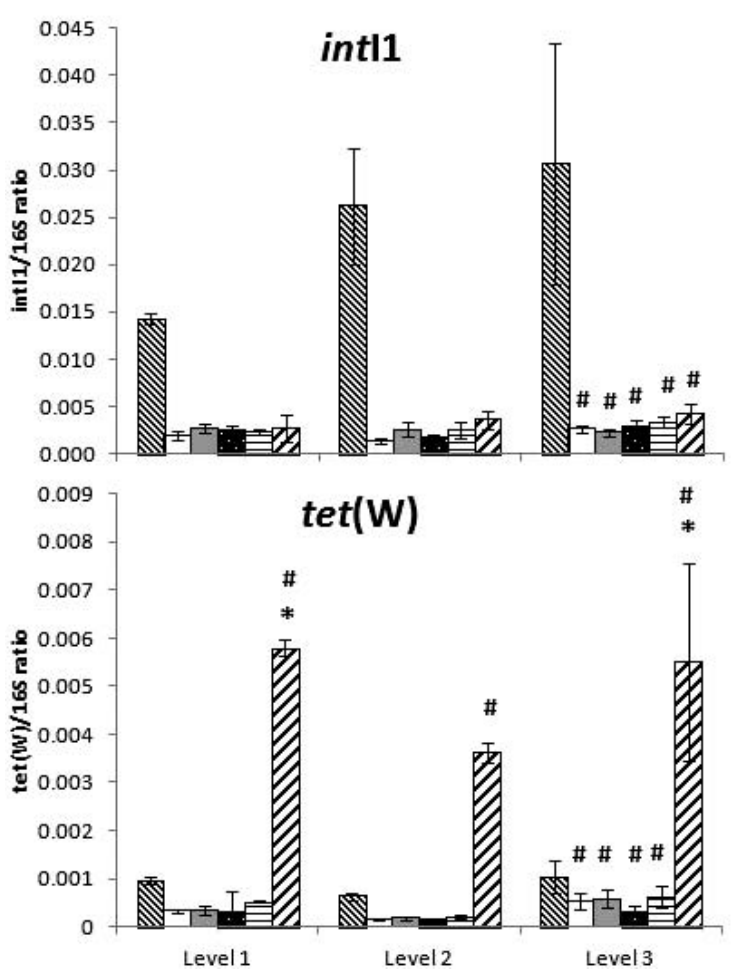

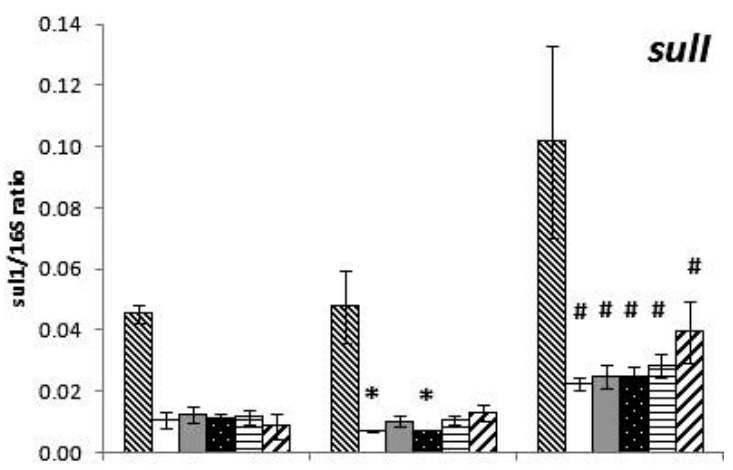

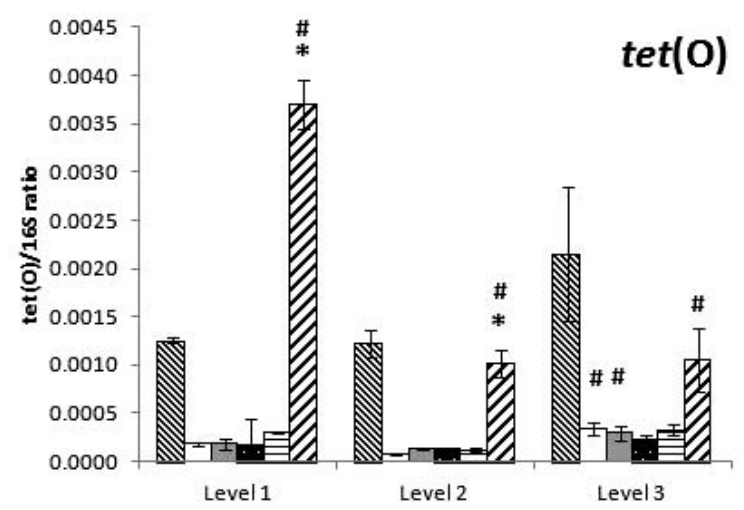

Figure 2-Antibiotic resistance genes (ARG) and int1 ratios in the raw feed sludge (feed), test digesters (nanosilver [Ag NP], ionic silver, and sulfamethoxazole [SMX]), thermophilic control digester (thermo control), and mesophilic control digester (meso control). Error bars represent standard error of four to six samples collected at steady state every 3 days over 1.5 to 2 solids retention times for dosing Levels 1, 2, and 3.

provided as ARG copy numbers normalized to $16 \mathrm{~S}$ bacterial rRNA (ARG ratio) as well as ARG copy number per microliter of sludge (un-normalized ARGs). Normalization accounts for variability in DNA extraction efficiencies and biomass between samples. The antibiotic resistance gene ratios shown in Figure 2 can be thought of as roughly representing an average gene count per bacteria cell and as such, can mask increases or decreases in un-normalized ARG copy numbers as a result of biomass growth or death. For this reason, un-normalized ARG data are also provided (Figure 3).

There was no consistent trend of ARG copy numbers or ratios with respect to dosing concentration for any of the digesters. Antibiotic resistance gene ratios in test digesters (Ag NPs, ionic silver, SMX) were the same as the thermophilic control digester $(P>0.05)$ for all genes during all sampling periods, except for
sulI and sulII $(P<0.05)$ that were lower in the Ag NPs and SMX digesters at Level $2(0.1 \mathrm{mg}-\mathrm{Ag} / \mathrm{L}$ and $5 \mathrm{mg}$-SMX/L, respectively) (Figure 2," symbol). Analysis using un-normalized ARGs (Figure 3, " symbol) also showed the same result of test digesters predominantly being the same as the thermophilic control digester. However, the exceptions were $\operatorname{tet}(\mathrm{O})$ in the ionic silver digester at Level $1(0.01 \mathrm{mg}-\mathrm{Ag} / \mathrm{L})$, sulII in the Ag NP and SMX digesters at Level $2(0.1 \mathrm{mg}-\mathrm{Ag} / \mathrm{L}$ and $5 \mathrm{mg}-\mathrm{SMX} / \mathrm{L}$, respectively), and tet $(\mathrm{O})$ in the Ag NP digester at Level $3(1.0 \mathrm{mg}-\mathrm{Ag} / \mathrm{L})$.

Effect of Digester Temperature on Antibiotic Resistance Genes. In comparing digested sludge to raw sludge feed (Figures 2, \# symbol), the ARG ratios in the test digesters and the thermophilic control digester were significantly different (lower) from the raw sludge feed $(P<0.05)$. Exceptions included intI1, sulI, and $\operatorname{tet}(\mathrm{W})$ in all digesters during Level 3 and $\operatorname{tet}(\mathrm{O})$ in the 

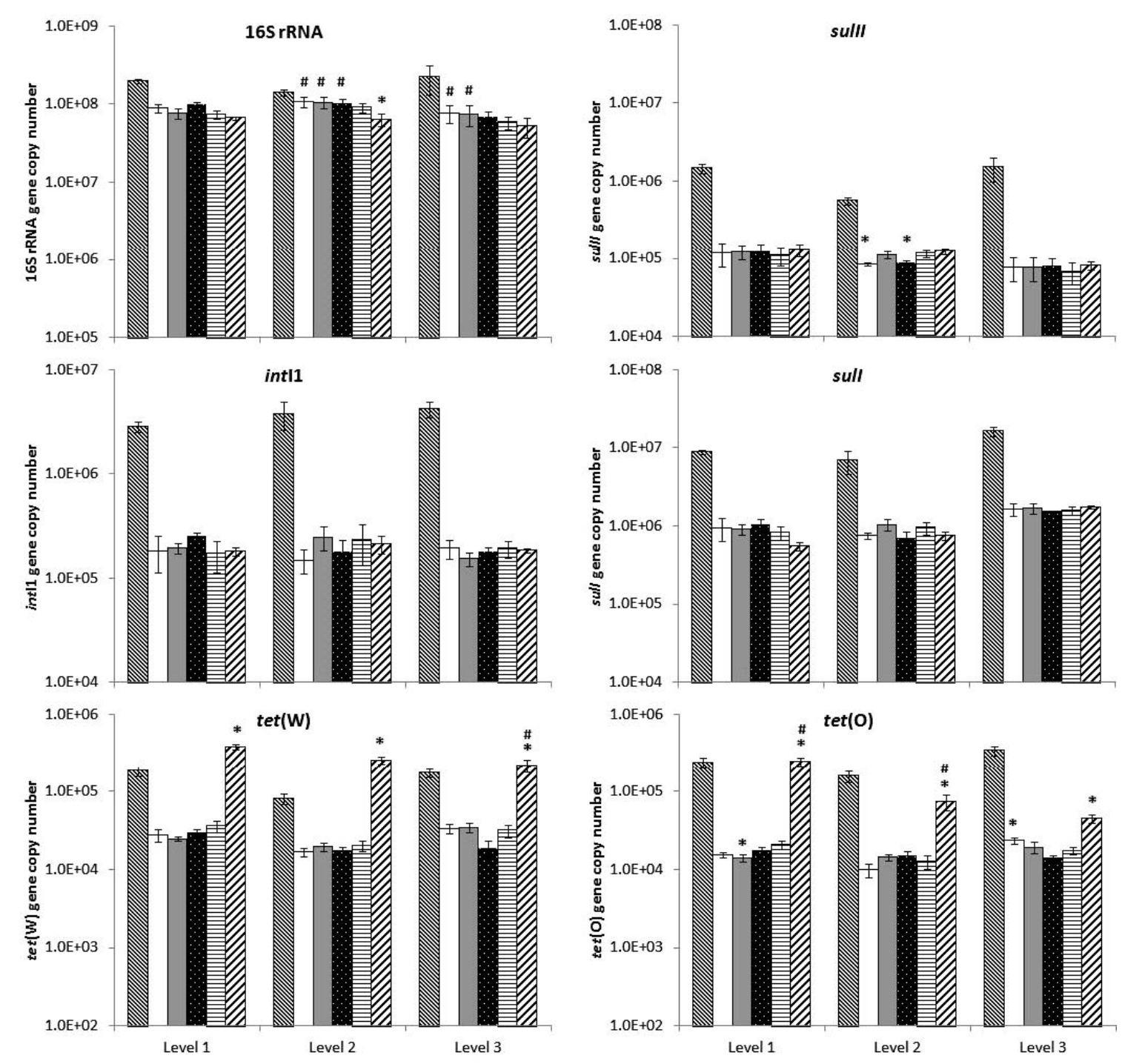

$\mathbb{\mathbb { N }}$ Feed $\square$ Nanosilver $\square$ lonic silver SMX $\mathbf{E}$ Thermo Control $Z$ Meso Control

* $p<0.05$ ARG ratio in test digester is different (higher or lower) than the thermophilic control digester.

\# ARG ratio in digester is the same or higher than raw sludge.

Figure 3-Quantities of antibiotic resistance genes (ARGs) and int11and 16S rRNA gene copy numbers (number per $\mu \mathrm{L}$ sludge) in raw feed sludge (feed), test digesters (nanosilver [Ag NP], ionic silver, and sulfamethoxazole [SMX]), thermophilic control digester (thermo control), and mesophilic control digester (meso control). Error bars represent standard error of four to six samples collected at steady state every 3 days over 1.5 to 2 solids retention times for dosing Levels 1, 2, and 3.

ionic silver and Ag NP digesters during Level 3. However, the $P$ values of these exceptions were small $(P<0.09)$ and the result of the high variability of the feed ARG ratios stemming from storage conditions. Statistical analysis using un-normalized gene copy (Figure 3, \# symbol) showed all ARGs in thermophilic digesters were lower than the raw sludge feed. The unnormalized gene data also shows that the $16 \mathrm{~S}$ rRNA gene was lower in Ag NP and ionic silver digesters during Level 2 and Level 3 and the SMX digester during Level 2.

tet $(\mathrm{O})$ and tet $(\mathrm{W})$ ratios in the mesophilic control digester were the same or higher from the raw sludge feed for all sampling periods. Similar to the thermophilic digesters, intI1 and sulI ratios in the mesophilic control digester and raw feed were the same during Level 3 . Notably, the $P$ values of these exceptions were small $(0.10<P<0.09)$, likely a result of the high variability of the feed ARG ratios. Statistical analysis using un-normalized ARGs (Figure 3, \# symbol) shows similar results as ARG ratios where tet(W) gene copy numbers in Levels 1, 2, and 3 , and tet $(\mathrm{O})$ gene copy numbers in Levels 1 and 2 were the same or higher in the mesophilic digester compared to raw sludge.

Effect of Raw Sludge Antibiotic Resistance Genes on Digester Antibiotic Resistance Genes. Antibiotic resistance gene ratios and un-normalized levels in refrigerated $\left(4^{\circ} \mathrm{C}\right)$ raw 

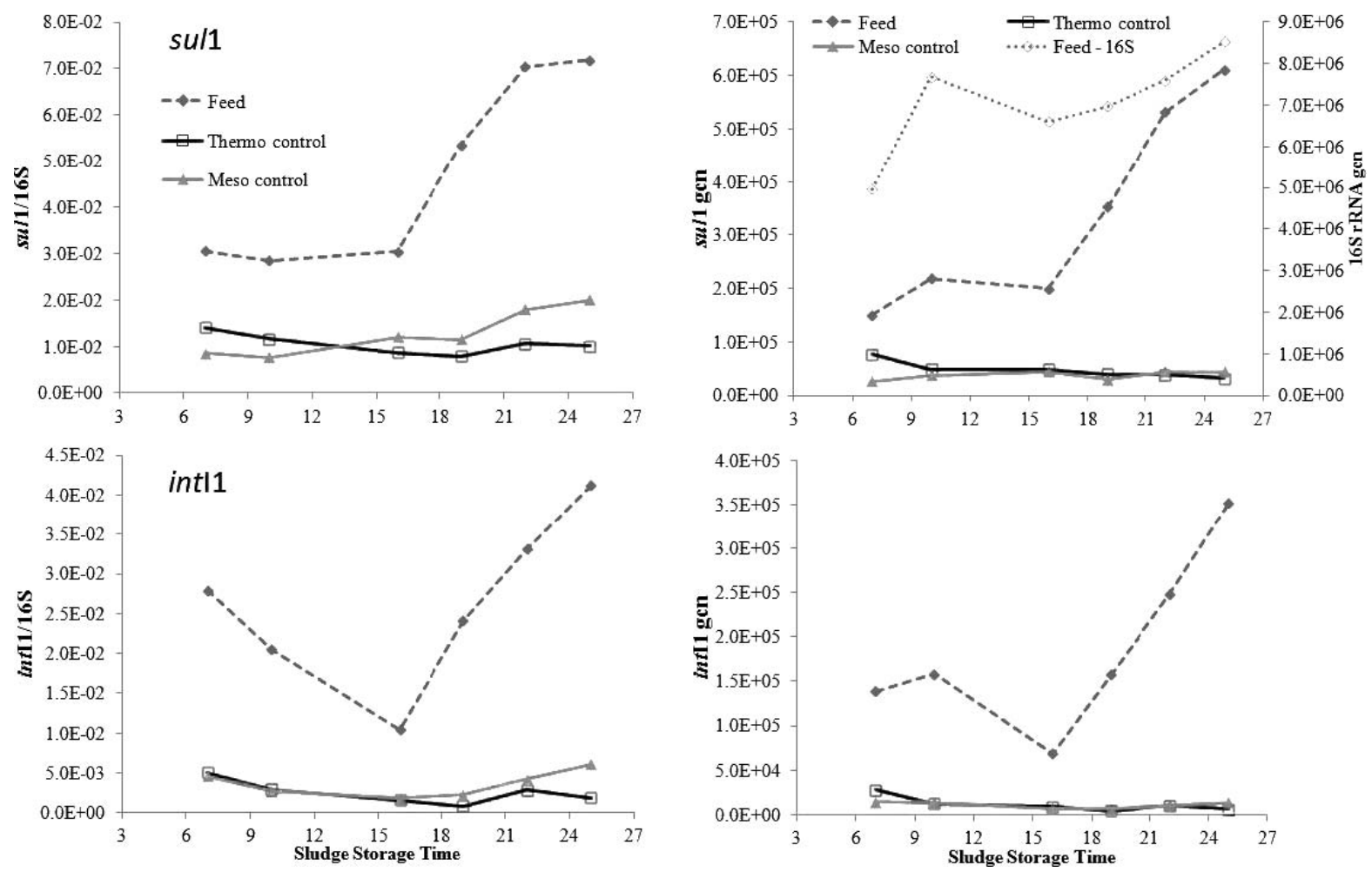

Figure 4-sul1 and int1 gene copy numbers and antibiotic resistance gene (ARG) ratios during the dosing Level 2 steady state sampling period. Each data point represents a single DNA extraction from one sample collected from the respective digester or feed on the given day. 16S rRNA, int1, and sul1 gene copy numbers were analyzed via quantitative polymerase chain reaction in triplicate on aliquots from the same extracted DNA.

sludge increased during the approximately 4- to 6-week storage period. sulI and intI1 ARGs in the raw sludge increased as much as seven- and four-fold, respectively, whereas the $16 \mathrm{~S}$ bacteria rRNA less than doubled. sulII, tet $(\mathrm{O})$, and tet $(\mathrm{W})$ genes did not increase. The Level 2 study period coincided with the use of middle-age to old sludge and resulted in increasing sulI and int $\mathrm{I} 1$ ARG ratios in raw sludge feed with time and high variation. Transition from old to new feed sludge during the Level 3 sampling period similarly resulted in high variation in ARGs.

Increasing levels of ARGs in the raw sludge during extended refrigerated storage of the feed afforded the opportunity to examine digester performance with increasing ARG levels in the feed. During two separate study periods, ARG ratio and copy numbers remained constant in both mesophilic and all thermophilic test and control digesters, regardless of the feed ARG content (Figure 4, only Level 2 data for control digesters shown). It is not known whether the extended storage time, low temperature, lack of mixing, or a combination induced the increase in ARGs.

\section{Discussion}

Effect of Antibiotic Resistance Gene Nanoparticles on Digester Performance. Recent studies of nanosilver in sludge have confirmed that Ag NPs readily bind with sulfide (Kaegi et al., 2011) and form individual and small aggregates of silver sulfide nanoparticles (Kim et al., 2010). Based on these studies, it is likely that amended ionic silver and Ag NPs were rapidly and completely converted to sulfidized silver.
Although the environmental fate of Ag NPs is now widely accepted, the mechanism(s) of their toxicity is still under investigation-sometimes with conflicting results. At present, it is difficult to ascertain whether the antimicrobial properties of Ag NPs are caused by leaching of the silver ion, nanoscale interactions with bacteria based on size and morphology, or a combination thereof (Morones et al., 2005; Pal et al., 2007; Sotiriou and Pratsinis, 2010). Reinsch et al. (2012) reported that Escherichia coli inhibition is reduced with increased sulfidation of Ag NPs. That study also highlighted that Ag NPs can be sulfidized to different extents; that is, fully or partially enveloped/passivated. The authors also emphasized that variable levels of sulfidation imparted differences in toxicity that were seemingly based on the remaining level of exposed silver. For this reason, simply stating sulfidized or non-sulfidized might not be an adequate descriptor to describe the level of toxicity.

In this study, both Ag NPs and ionic silver added at concentrations up to $1 \mathrm{mg}-\mathrm{Ag} / \mathrm{L}$ did not have an observable effect on digester performance. It is possible that toxicity was not observed because of the low concentrations of Ag NPs used in the study or the likely sulfidation of Ag NPs to form silver sulfide. The no-observed-effect of ionic silver on digester performance is not surprising. The toxicity of metallic or bulk silver is attributed to the aqueous concentration of the free ion $\mathrm{Ag}^{+}$. Consequently, processes that reduce free ion concentrations by binding with other elements or preventing the binding of the free ion to cells will reduce toxicity (Ratte, 1999). Lytle (1984) and Bard et al. (1976) found that silver was converted 
predominately to silver sulfide and accumulated in the sludge biomass during wastewater treatment. Indeed, the solubility product $\left(K_{\mathrm{sp}}\right)$ of silver sulfide is approximately $10^{-41}$. Bard and colleagues also investigated the effect of various forms of silver on oxygen uptake rates by activated sludge biomass. They found that $100 \mathrm{mg}-\mathrm{Ag} / \mathrm{L}$ as silver sulfide did not inhibit respiration, whereas $10 \mathrm{mg}-\mathrm{Ag} / \mathrm{L}$ as free ion derived from silver nitrate and silver chloride led to an 84 and $43 \%$ inhibition, respectively. The latter findings suggest that although bound silver is not biologically active, free silver ions, and to a lesser extent aqueous complexes, inhibit microbial activity.

Effect of Sulfamethoxazole on Digester Performance. Only speculations can be made regarding the mechanistic effects of SMX on digester operations because published literature on the effect of antibiotics on anaerobic digestion and Archaea is limited (Dridi et al., 2001; Hilpert et al., 1986; Sanz et al., 1996). Because published literature on the effect of antibiotics on anaerobic digestion and Archaea is limited (Dridi et al., 2001; Hilpert et al., 1986; Sanz et al., 1996), only speculations can be made regarding the mechanistic effects of SMX on digester operations. The antibiotic action of SMX in bacteria is mediated by competition with the precursor para-aminobenzoic acid (PABA) for the catalyst site on the enzyme dihydropteroate synthetase that converts PABA to a precursor of folic acid. DiMarco et al. (1990) reported that PABA is also a precursor in the biosynthesis of tetrahydromethanopterin (H4MPT), a cofactor in methanogensis. Tetrahydromethanopterin (among other enzymes) catalyze the conversion of carbon dioxide to methane using hydrogen as an electron donor in hydrogenotrophic methanogens (Rouviere and Wolfe, 1988). Lessner (2009) reported H4MPT to be a structural analog to the enzyme tetrahydrosarcinapterin (H4SPT), which is involved in the shuttling of carbon from acetate's carboxyl group to methane by acetoclastic methanogens.

Dimitru et al. (2003) found that a competitive relationship between PABA and various PABA-like inhibitors for the active site on an enzyme (4-( $\beta$-d-ribofuranosyl)aminobenzene- $5^{\prime}$ phosphate synthase) that catalyzes the first step in the biosynthesis of H4MPT. Although not reported in other studies, it is hypothesized that inhibition of H4SPT and H4MPT biosynthesis - in this case as a result of competition of SMX and PABA-results in reduced methanogenic activity of acetoclastic and hydrogenotrophic methanogens. This could explain the accumulation of acetic acid, other VFAs, and hydrogen observed in this study. However, Fountoulakis et al. (2004) reported that SMX up to $400 \mathrm{mg} / \mathrm{L}$ had no inhibitory effect on acetoclastic methanogens. The increase in gas volume could be the result of carbon dioxide stripping at the lower $\mathrm{pH}$; however, there was no measured increase in the carbon dioxide proportion. The reason(s) behind the observed increases in gas volume with no increase in carbon dioxide proportion in this study are unclear.

Effect of Silver Nanoparticles and Sulfamethoxazole on Antibiotic Resistance Genes. The lack of a consistent trend of ARG copy numbers with ionic silver dosing concentration is not surprising, in part because other studies (Bard et al., 1976; Ratte, 1990) predict removal of ionic silver from solution by sulfide binding and subsequent loss of toxicity. The antimicrobial property of Ag NPs might also result from size-dependent nanoscale interactions with bacteria. However, Ag NPs at the environmentally-relevant concentrations tested in this study (0.01 to $1.0 \mathrm{mg}-\mathrm{Ag} / \mathrm{L}$ ) also did not elicit an ARG response.

The lack of response of sulI and sulII ARGs to addition of SMX is surprising-particularly at the dose above the MIC (Level $3=50 \mathrm{mg}$-SMX/L, $\approx 5 \mathrm{~g}$-SMX $/ \mathrm{kg}$ total solids). It seems reasonable that a high nutrient, microbially-dense environment in the presence of selection pressures might result in an increase in ARGs. In this regard, other researchers have reported increased ARG transcription in response to even sub-MIC antibiotic levels (e.g., Davies et al., 2006). Studies investigating the fate of ARGs in dairy lagoons have also reported a positive correlation of ARGs with increased antibiotic concentrations (McKinney et al., 2010; Pei et al., 2007). Pei and colleagues conducted studies at 4 and $20^{\circ} \mathrm{C}$ with an SMX concentration of $20 \mathrm{mg} / \mathrm{L}$; McKinney et al. (2010) analyzed environmental samples collected at ambient temperatures over four seasons (no specific temperatures reported) and with SMX concentrations up to $840 \mu \mathrm{g} / \mathrm{kg}$. In addition, it is widely accepted that the mesophilic gastrointestinal tract of humans and farm animals also gives rise to ARBs under antibiotic selection pressures via mutation or horizontal transfer (Levy and Marshall, 2004).

Correlation of intI1 with Antibiotic Resistance Genes. Class 1 integrons are mobile genetic elements that often contain multiple ARGs. Selection for one ARG can result in the selection of all ARGs housed on the integron. As such, int I1 could be an important indicator of ARG propagation. int 11 in digested sludge had significant correlation $(P<0.05)$ with all genes analyzed, although the strength of the correlation varied between genes as strong (sulI, $\left.r^{2}=0.74\right)$, moderate (sulII, $r^{2}=$ 0.66 and tet $\left.(\mathrm{O}), r^{2}=0.55\right)$, and weak $\left(\operatorname{tet}(\mathrm{W}), r^{2}=0.04\right)$. Strong correlation of sulI and int 11 is not surprising because sulI is typically associated with Class 1 integrons (Mazel, 2006).

Effect of Digestion Temperature on Antibiotic Resistance Genes. In comparing the thermophilic and mesophilic control digesters study results, the ARG response was found to be genespecific. This suggests that both thermophilic and mesophilic digestion have similar removals of sulI, sulII, and intI1 genes, ranging from 1 - to $2-\log$ reductions. Although thermophilic digesters also consistently reduced $\operatorname{tet}(\mathrm{O})$ and tet $(\mathrm{W})$ genes, at times in the mesophilic digester these genes increased relative to the feed. Ma et al. (2011) and Diehl and Lapara (2010) also reported gene-specific responses to digestion temperature with respect to tet genes. Diehl and Lapara (2010) further reported temperature dependence with the int 11 gene; however, this study and $\mathrm{Ma}$ et al. (2011) both found consistent reduction of the intI1 gene in either mesophilic or thermophilic digestion.

Ahring et al. (2001) reported that at $55{ }^{\circ} \mathrm{C}$, bacterial rRNA contributed 74 to $79 \%$ and archaeal rRNA contributed 18 to $23 \%$ of the universal probe, respectively. At $65{ }^{\circ} \mathrm{C}$, the archaeal contribution increased to 34 to $36 \%$ whereas the bacterial contribution decreased to 57 to $62 \%$. Archaea are resistant to most antibiotics because their physiology and structure differ from bacteria such that antibiotic targets are not recognized. As such, an increase in Archaea population relative to Bacteria would reduce the total number of possible hosts and ARGs embodied therein. However, a $16 \mathrm{~S}$ bacterial rRNA primer was used in this study, so a reduction in the ARG ratio reflects the reduction of ARG copy numbers relative to bacteria. This suggests that the number of ARGs per bacterial cell were reduced overall, not just reduced as a result of the reduction of bacterial population relative to the archaeal population. 
Although the shift in microbe composition between Bacteria and Archaea might account for some loss of total ARGs, this loss should have been accounted for by normalizing ARG copy numbers to $16 \mathrm{~S}$ bacterial rRNA gene copy numbers.

Effect of Raw Sludge Antibiotic Resistance Gene Content on Digester Antibiotic Resistance Gene Content. Unnormalized ARGs and ARG ratios remained constant in both mesophilic and thermophilic control digesters during addition of raw sludge that varied in the levels of intI1 (Figure 4). However, Figures 2 and 3 show a similar pattern of ARG content in the raw sludge feed and digesters. For example, sulI and int I1 levels in the raw sludge increased from Level 1 through Level 3, which spanned approximately 6 months. Similarly, sulI and intI1 levels in the digested sludge from all digesters also increased from Level 1 through Level 3 time periods. Further research is necessary to determine the effect of raw sludge ARG content on digester ARG content.

Antibiotic Resistance Gene Attenuation Mechanisms. In digestion, the fate of ARGs depends on the cumulative effect of the following: (1) proliferation/attenuation of ARGs with replicating/dying raw sludge bacteria or digester bacteria, (2) differential replication of ARG-containing raw sludge or digester bacteria (enrichment), (3) horizontal transfer of ARGs from raw sludge bacteria to digester bacteria, and (4) mutation. Mutation can be discounted in this study because it is unlikely that mutations would give rise to the specific genes recognized by the QPCR assays.

Based on experimental results, it appears that the higher temperatures and/or endogenous conditions used in mesophilic and thermophilic anaerobic digestion can create an environment that is not conducive to horizontal transfer, or might support a microbial community that is not compatible with incoming raw sludge bacteria for horizontal transfer of the ARGs. Indeed, diversity among bacteria is reduced in thermophilic digestion relative to mesophilic digestion (LaPara et al., 2000; Leven et al., 2007; Wilson et al., 2008). Thus, as pointed out by Ma et al. (2011), restriction of the host range might play a role in attenuation of ARGs in thermophilic digestion. It also seems plausible that the differences in the microbial community are the reason behind varied individual gene response to mesophilic and thermophilic conditions.

\section{Conclusions}

The following are the major findings of this study:

- Effect of silver nanoparticles and SMX on digester performance. Neither direct application of Ag NPs nor ionic silver affected digester performance as assessed by $\mathrm{pH}$, alkalinity, VFA, and VSR. Low concentrations of antibiotic SMX $(<5 \mathrm{mg} / \mathrm{L})$ did not affect digester performance; however, the highest dose $(50 \mathrm{mg} / \mathrm{L})$ resulted in digester souring where $\mathrm{pH}$ and alkalinity decreased as a result of the accumulation of VFAs. It is possible that SMX inhibits the synthesis of methanopterin, which is a key enzyme in hydrogenotrophic methanogenesis.

- Effect of silver nanoparticles and SMX on antibiotic resistance genes. Antibiotic resistance gene ratios and unnormalized copy numbers did not increase relative to the thermophilic control in response to the amendments added to test thermophilic digesters. Typically, ARG ratios and un-normalized copy numbers were the same (sulI, sulII, and intI1) or higher (tet ARGs) in mesophilic digestion (37 ${ }^{\circ} \mathrm{C}, 20$-day SRT) than thermophilic digestion $\left(53{ }^{\circ} \mathrm{C}, 12\right.$-day SRT) when using the same feed.

- Effect of digestion temperature on ARGs. Test and control thermophilic digesters consistently reduced but did not eliminate levels of all genes that were analyzed (sulI, sulII, int $\mathrm{I} 1$, tet $(\mathrm{O})$, and tet $(\mathrm{W}))$. The mesophilic digester also reduced levels of sulI, sulII, and int $\mathrm{I} 1$ genes, but levels of $\operatorname{tet}(\mathrm{O})$ and $\operatorname{tet}(\mathrm{W})$ were the same or higher than in raw sludge.

- Effect of raw sludge ARG content on digester ARG content. Antibiotic resistance gene ratios in digested sludge remained constant under increasing concentration of feed ARGs. Quantities of the five ARGs in the raw sludge ranged from $10^{4}$ to $10^{8}$ copies per $\mu \mathrm{L}$ of sludge, whereas quantities of sulII, tet $(\mathrm{O})$, tet $(\mathrm{W})$ were consistently an order of magnitude lower than quantities of int $\mathrm{I} 1$ and sulI. Quantities in digested sludge ranged from $10^{3}$ to $10^{6}$ as a result of a 1-log reduction of ARGs (2-log reduction for int $\mathrm{I} 1)$ during anaerobic digestion.

In summary, this study shows that mesophilic and thermophilic anaerobic digestion reduces but does not eliminate ARG loading to the environment. Thermophilic digestion reduced a wide variety of ARGs, whereas tetracycline genes were not reduced and sometime increased in mesophilic digestion. ARG ratios in digested sludge (reactor effluent) remained constant despite the application of selection pressures and variable feed ARG concentrations suggesting that the digester operating conditions themselves are the primary factor that governs the composition of the bacterial community and the subsequent prevalence of ARGs. Future studies that investigate the effect of stress conditions on ARG horizontal transfer and persistence and the fate of ARGs post-digestion are warranted.

\section{Acknowledgments}

This work was supported by U.S. Environmental Protection Agency STAR (Science to Achieve Results) Grant R834856, National Science Foundation Chemical, Bioengineering, and Transport Systems CAREER award \#0852942, and Virginia Tech Institute for Critical Technology and Applied Science seed funding and award TSTS 11-26. Jennifer Miller was supported by the Charles E. Via, Jr. Department of Civil and Environmental Engineering Via Scholarship and Virginia Tech Graduate School Cunningham Fellowship. The findings of this study do not necessarily reflect the views of the supporting entities.

Submitted for publication June 7, 2012; accepted for publication September 17, 2012.

\section{References}

Ahring, B. K.; Ibrahim, A. A.; Mladenovska, Z. (2001) Effect of Temperature Increase from 55 to 65 Degrees $C$ on Performance and Microbial Population Dynamics of an Anaerobic Reactor Treating Cattle Manure. Water Res., 35 (1), 2446-2452.

Allen, H. K.; Donato, J.; Wang, H. H.; Cloud-Hansen, K. A.; Davies, J.; Handelsman, J. (2010) Call of the Wild: Antibiotic Resistance Genes in Natural Environments. Nature Rev. Microbiol., 8 (4), 251-259.

American Public Health Association; American Water Works Association; Water Environment Federation (1995) Standard Methods for the Examination of Water and Wastewater, 19th ed.; American Public Health Association: Washington, D.C. 
Bard, C. C.; Murphy, J. J.; Stone, D. L.; Terhaar, C. J. (1976) Silver in Photoprocessing Effluents. J. Water Pollut. Control Fed., 48 (2), 389394.

Benn, T. M.; Westerhoff, P. (2008) Nanoparticle Silver Released into Water from Commercially Available Sock Fabrics. Environ. Sci. Technol., 42 (1), 4133-4139.

Choi, O. K.; Hu, Z. Q. (2009) Nitrification Inhibition by Silver Nanoparticles. Water Sci. Technol., 59 (9), 1699-1702.

Clement, J.; Jarrett, P. (1994) Antibacterial Silver. Metal Based Drugs, 1 (5-6), 467-482.

Cunningham, J. H.; Lin, L. S. (2010) Fate of Amoxicillin in MixedCulture Bioreactors and Its Effects on Microbial Growth and Resistance to Silver Ions. Environ. Sci. Technol., 44 (5), 1827-1832.

Davies, J.; Spiegelman, G. B.; Yim, G. (2006) The World of Subinhibitory Antibiotic Concentrations. Current Opin. Microbiol., 9 (5), 445453.

Diehl, D. L.; Lapara, T. M. (2010) Effect of Temperature on the Fate of Genes Encoding Tetracycline Resistance and the Integrase of Class 1 Integrons within Anaerobic and Aerobic Digesters Treating Municipal Wastewater Solids. Environ. Sci. Technol., 44 (23), 91289133.

DiMarco, A. A.; Bobik, T. A.; Wolfe, R. S. (1990) Unusual Coenzymes of Methanogenesis. Ann. Rev. Biochem., 59, 355-394.

Dridi, B.; Fardeau, M. L.; Ollivier, B.; Raoult, D.; Drancourt, M. (2011) The Antimicrobial Resistance Pattern of Cultured Human Methanogens Reflects the Unique Phylogenetic Position of Archaea. J. Antimicro. Chemother, 66 (9), 2038-2044.

Dumitru, R.; Palencia, H.; Schroeder, S. D.; DeMontigny, B. A.; Takacs, J. M.; Rasche, M. E.; Miner, J. L.; Ragsdale, S. W. (2003) Targeting Methanopterin Biosynthesis to Inhibit Methanogenesis. Appl. Environ. Microbiol., 69 (12), 7236-7241.

Fountoulakis, M.; Drilla, P.; Stamatelatou, K.; Lyberatos, G. (2004) Toxic Effect of Pharmaceuticals on Methanogenesis. Water Sci. Technol., 50 (5), 335-340.

Ghosh, S.; Ramsden, S. J.; LaPara, T. M. (2009) The Role of Anaerobic Digestion in Controlling the Release of Tetracycline Resistance Genes and Class 1 Integrons from Municipal Wastewater Treatment Plants. Appl. Microbiol. Biotechnol., 84 (4), 791-796.

Gottschalk, F.; Sonderer, T.; Scholz, R. W.; Nowack, B. (2009) Modeled Environmental Concentrations of Engineered Nanomaterials $\left(\mathrm{TiO}_{2}\right.$, $\mathrm{ZnO}, \mathrm{Ag}, \mathrm{CNT}$, Fullerenes) for Different Regions. Environ. Sci. Technol., 43 (24), 9216-9222.

Hilpert, R.; Winter, J.; Hammes, W.; Kandler, O. (1981) The Sensitivity of Archaebacteria to Antibiotics. Zentralblatt fur Bakteriologie Mikrobiologie and Hygiene I Abteilung Originale C-Allgemeine Angewandte and Okologische Mikrobiologie, 2 (1), 11-20.

Kaegi, R.; Voegelin, A.; Sinnet, B.; Zuleeg, S.; Hagendorfer, H.; Burkhardt, M.; Siegrist, H. (2011) Behavior of Metallic Silver Nanoparticles in a Pilot Wastewater Treatment Plant. Environ. Sci. Technol., 45 (9), 3902-3908.

Kim, S.; Aga, D. S. (2007) Potential Ecological and Human Health Impacts of Antibiotics and Antibiotic-Resistant Bacteria from Wastewater Treatment Plants. J. Toxicol. Environ. Health B Crit. Rev., 10 (8), 559-573.

Kim, B.; Park, C. -S.; Murayama, M.; Hochella, M. F. (2010) Discovery and Characterization of Silver Sulfide Nanoparticles in Final Sewage Sludge Products. Environ. Sci. Technol., 44 (19), 7509-7514.

Kiser, M. A.; Ryu, H.; Jang, H.; Hristovski, K.; Westerhoff, P. (2010) Biosorption of Nanoparticles to Heterotrophic Wastewater Biomass. Water Res., 44 (14), 4105-4114.

Kohanski, M. A.; DePristo, M. A.; Collins, J. J. (2010) Sublethal Antibiotic Treatment Leads to Multidrug Resistance via Radical-Induced Mutagenesis. Mol. Cell., 37 (3), 311-320.

Kolpin, D. W.; Furlong, E. T.; Meyer, M. T.; Thurman, E. M.; Zaugg, S. D.; Barber, L. B.; Buxton, H. T. (2002) Pharmaceuticals, Hormones, and Other Organic Wastewater Contaminants in U.S. Streams, 1999-
2000: a National Reconnaissance. Environ. Sci. Technol., 36 (6), 1202-1211.

LaPara, T. M.; Nakatsu, C. H.; Pantea, L.; Alleman, J. E. (2000) Phylogenetic Analysis of Bacterial Communities in Mesophilic and Thermophilic Bioreactors Treating Pharmaceutical Wastewater. Appl. Environ. Microbiol., 66 (9), 3951-3959.

Lessner, D. (2009) Methanogenesis Biochemistry. In Encyclopedia of Life Sciences; Ferry, J. G., Ed.; Nature Publishing Group: London.

Leven, L.; Eriksson, A. R. B.; Schnurer, A. (2007) Effect of Process Temperature on Bacterial and Archaeal Communities in Two Methanogenic Bioreactors Treating Organic Household Waste. FEMS Microbiol. Ecol., 59 (3), 683-693.

Levy S. B.; Marshall, B. (2004) Antibacterial Resistance Worldwide: Causes, Challenges and Responses. Nature Med., 10 (12 Suppl.), S122-S129.

Liang, Z.; Das, A.; Hu, Z. (2010) Bacterial Response to a Shock Load of Nanosilver in an Activated Sludge Treatment System. Water Res., 44 (18), 5432-5438.

Loh, J. V.; Percival, S. L.; Woods, E. J.; Williams, N. J.; Cochrane, C. A. (2009) Silver Resistance in MRSA Isolated from Wound and Nasal Sources in Humans and Animals. Int. Wound J., 6 (1), 32-38.

Lytle, P. (1984) Fate and Speciation of Silver in Publicly Owned Treatment Works. Environ. Toxicol. Chem., 3 (1), 21-30.

Ma, Y.; Wilson, C. A.; Novak, J. T.; Riffat, R.; Aynur, S.; Murthy, S.; Pruden, A. (2011) Effect of Various Sludge Digestion Conditions on Sulfonamide, Macrolide, and Tetracycline Resistance Genes and Class 1 Integrons. Environ. Sci. Technol., 45 (18), 7855-7861.

Mazel, D. (2006) Integrons: Agents of Bacterial Evolution. Nature Rev. Microbiol., 4 (8), 608-620.

McKinney, C. W.; Loftin, K. A.; Meyer, M. T.; Davis, J. G.; Pruden, A. (2010) tet and sul Antibiotic Resistance Genes in Livestock Lagoons of Various Operation Type, Configuration, and Antibiotic Occurrence. Environ. Sci. Technol., 44 (16), 6102-6109.

Morones, J. R.; Elechiguerra, J. L.; Camacho, A.; Holt, K.; Kouri, J. B.; Ramirez, J. T.; Yacaman, M. J. (2005) The Bactericidal Effect of Silver Nanoparticles. Nanotechnol., 16 (1), 2346-2353.

Muhling, M.; Bradford, A.; Readman, J. W.; Somerfield, P. J.; Handy, R. D. (2009) An Investigation into the Effects of Silver Nanoparticles on Antibiotic Resistance of Naturally Occurring Bacteria in an Estuarine Sediment. Mar. Environ. Res., 68, 278-283.

Nagulapally, S. R.; Ahmad, A.; Henry, A.; Marchin, G. L.; Zurek, L.; Bhandari, A. (2009) Occurrence of Ciprofloxacin-, Trimethoprim-, Sulfamethoxazole-, and Vancomycin-Resistant Bacteria in a Municipal Wastewater Treatment Plant. Water Environ. Res., 81 (1), 82-90.

National Institute of Allergy and Infectious Diseases (NIAID). 2012. Antimicrobial (Drug) Resistance: Quick Facts. http://www.niaid.nih. gov/topics/antimicrobialResistance/Understanding/Pages/ quickFacts.aspx (accessed Jan 20, 2012).

Pal, S.; Tak, Y. K.; Song, J. M. (2007) Does the Antibacterial Activity of Silver Nanoparticles Depend on the Shape of the Nanoparticle? A Study of the Gram-Negative Bacterium Escherichia coli. Appl. Environ. Microbiol., 73 (6), 1712-1720.

Pavlostathis, S. G.; Maeng, S. K. (2000) Fate and Effect of Silver on the Anaerobic Digestion Process. Water Res., 34 (16), 3957-3966.

Pei, R.; Cha, J.; Carlson, K. H.; Pruden, A. (2007) Response of Antibiotic Resistance Genes (ARG) to Biological Treatment in Dairy Lagoon Water. Environ. Sci. Technol., 41 (14), 5108-5113.

Pruden, A.; Pei, R.; Storteboom, H.; Carlson, K. H. (2006) Antibiotic Resistance Genes as Emerging Contaminants: Studies in Northern Colorado. Environ. Sci. Technol., 40 (23), 7445-7450.

Ratte, H. T. (1999) Bioaccumulation and Toxicity of Silver Compounds: a Review. Environ. Toxicol. Chem., 18 (1), 89-108.

Reinsch, B. C.; Levard, C.; Li, Z.; Ma, R.; Wise, A.; Gregory, K. B.; Brown, G. E.; Lowry, G. V. (2012) Sulfidation of Silver Nanoparticles 
Decreases Escherichia coli Growth Inhibition. Environ. Sci. Technol., 46 (13), 6992-7000.

Rouviere, P. E.; Wolfe, R. S. (1988) Novel Biochemistry of Methanogenesis. J. Biol. Chem., 263, 7913-7916.

Sanz, J. L.; Rodriguez, N.; Amils, R. (1996) The Action of Antibiotics on the Anaerobic Digestion Process. Appl. Microbiol. Biotechnol., 46 (5-6), 587-592.

Shafer, M. M.; Overdier, J. T.; Armstrong, D. E. (1998) Removal, Partitioning, and Fate of Silver and Other Metals in Wastewater Treatment Plants and Effluent-Receiving Streams. Environ. Toxicol. Chem., 17 (4), 630-641.

Solomon, S. D.; Bahadory, M.; Jeyarajasingam, A. V.; Rutkowsky, S. A.; Boritz, C.; Mulfinger, L. (2007) Synthesis and Study of Silver Nanoparticles. J. Chem. Educ., 84 (2), 322-325.

Sotiriou, G. A.; Pratsinis, S. E. (2010) Antibacterial Activity of Nanosilver Ions and Particles. Environ. Sci. Technol., 44 (14), 5649-5654.

Storteboom, H.; Arabi, M.; Davis, J. G.; Crimi, B.; Pruden, A. (2010) Identification of Antibiotic-Resistance-Gene Molecular Signatures
Suitable as Tracers of Pristine River, Urban, and Agricultural Sources. Environ. Sci. Technol., 44 (6), 1947-1953.

Summers, A. O. (2002) Generally Overlooked Fundamentals of Bacterial Genetics and Ecology. Clin. Infect. Dis., 34 (Suppl. 3), S85-S92.

U.S. Environmental Protection Agency (U.S. EPA). (2009) Targeted National Sewage Sludge Survey Sampling and Analysis Technical Report; EPA-822-R-08-016; U.S. Environmental Protection Agency, Office of Water: Washington, D.C.

Wilson, C. A.; Murthy, S. M.; Fang, Y.; Novak, J. T. (2008) The Effect of Temperature on the Performance and Stability of Thermophilic Anaerobic Digestion. Water Sci. Technol., 57 (2), 297-304.

Wilson, C. A. (2009) Mechanisms of Methanogenic Inhibition in Advanced Anaerobic Digestion. Ph.D. Dissertation, Virginia Tech, Blacksburg, Virginia.

Yang, Y.; Xu, M.; Wall, J. D.; Hu, Z. (2012) Nanosilver Impact on Methanogenesis and Biogas Production from Municipal Solid Waste. Waste Manage., 32 (5): 816-825. 